\title{
AZ ÁLHÍRJELENSÉG A KÖZÖSSÉGI OLDALAKON
}

\author{
Czeglédi Csilla - Veresné Valentinyi Klára - Borsos Eszter \\ Szira Zoltán - Varga Erika
}

\section{Összefoglalás}

Az utóbbi években hirfogyasztási szokásaink nagyon megváltoztak. Az újságok és folyóiratok papiralapú példányai helyett a közösségi média és az internetes hálózatépités népszerüvé vált a fiatalok, a középkorúak és az idöskoruak körében egyaránt. Megállapithatjuk azonban, hogy a fiatalok azok, akik a legnagyobb mértékben kapcsolódnak a közösségi médiához. Az ellenörizetlen információáramlás a téves információk és a hamis hirek megjelenéséhez is vezethet. Manapság alapvetö és létfontosságú készség vagy technika az a képesség, hogy megkülönböztessük a dezinformációt a valóságon alapuló, valódi hirektöl. Jelenleg folyó V4 nemzetközi kutatásunk keretén belül egy átfogó fókuszcsoportos kvalitativ kutatást végeztünk a szociális média és a bizalomépités területén. Kutatásunkat 6 fókuszcsoportban a Gödöllöi Szent István Egyetem budapesti képzési helyén folytattuk, hogy választ kaphassunk az olyan kérdésekre, mint pl. a hallgatók miért használják a közösségi médiát, mennyire fontos az önmegjelenités, a hálózatépités és az információkeresés a közösségi médiában, mennyire szórakoztató mindez számukra, és milyen veszélyekre kell figyelniük. A válaszok nagy részére számitottunk, ám néhány a várakozásokkal ellentétes volt.

Kulcsszavak: közösségi média, álhir, online, hirforrás, kommunikáció, poszt JEL: D83 


\title{
FAKE NEWS IN SOCIAL MEDIA
}

\begin{abstract}
Over the last few years our news consuming habits have changed a lot. Instead of paperbased copies of newspapers and magazines in circulation, social media and networking on the Internet have gained popularity among the young, middle aged and elderly alike. However, we can state that it is the young who are connected to social media to the greatest extent. As a result, the uncontrolled flow of information can also lead to the rise of misinformation and fake news. An essential and vital skill or technique nowadays is the ability to distinguish between disinformation and real, true news based on reality. Our current V4 international research included comprehensive focus group qualitative research on social media and trust building. Research was carried out in 6 focus groups at the Budapest Training Centre of Szent István University, Gödöllö to provide an answer to the issues of why students use social media, how important they find self-presentation, networking and information seeking in the social media, how fun it is for them, and what dangers they need to be aware of. Most of the answers were well expected by the researchers, however, some of them were contrary to the expectations.
\end{abstract}

Key words: social media, fake news, online, source of news, communication, post JEL: D83 


\section{Bevezetés}

Az elmúlt évtizedekben az olvasási szokások gyökeresen megváltoztak (Goyanes, 2014; Shu et al., 2017). A digitális platformok és a nyomtatott sajtó példányszámaiban bekövetkezett drasztikus hanyatlás azt jelzi, hogy a hagyományos hírforrások szerepét egyre inkább egy újfajta közeg tölti be (Meyer 2004; Ahlers, 2006), amely nem más, mint a közösségi média (Gil de Zuñiga, Weeks and Ardèvol-Abreu, 2017).

A Reuters Institute (2017) adatai szerint 36 ország online felhasználóinak több mint fele (54\%) a közösségi médiát használja hírforrásként, egytizedük (14\%) pedig az egyetlen, fö hírforrásként tekint rá.

Ez a digitális forradalom meginkább a kommunikáció területén mutatkozik. Gondoljunk csak olyan online platformokra, mint a Facebook, Twitter, Snapchat vagy YouTube, melyek lehetővé teszik az érzelmek, vélemények és információ megosztását.

A közösségi média hírfogyasztási szokásai azonban komoly aggodalomra is adnak okot, hisz lényegében ellenőrzés nélkül óriási mennyiségű újságírói tartalmat osztanak meg (Baum et al., 2017), és elvezetnek az álhírek fogalmáig, valamint azok gombamódszerü elterjedéséig (Gu et al., 2017).

\section{Szakirodalmi háttér}

Az álhír szót hallva a legtöbb ember a közösségi média posztjaira gondol, melyek fantasztikus, hihetetlen sztorikat újságolnak el.

Az álhírek terjesztése a közösségi médiában önkéntes alapon történik egy szervezet vagy egyén részéről, amikor a cél olyan információ „előállítása” és terjesztése, melynek egy része vagy egésze nem valós, azaz hamis, és ezt kihasználva a közösség véleményét befolyásolják, ellentéteket szítanak, a társadalmat polarizálják, vagy épp anyagi haszon reményében teszik mindezt.

Bár az igazság egy darabját is magában hordozhatja az álhír, ez kisarkítva, eltorzítva jelenik meg, a környezetéből kiragadva és hamis részletekkel tarkítva. Az álhír sokszor valódi hírnek tűnik, mivel szavahihető, független szervezeteket utánoz.

Az álhír elnevezés nem egy terminus technicus, inkább politikai koncepció, amely konceptuális keretekbe ágyazódik (Lakoff 2002). Az álhír nem spontán, publikálási célokból jön létre, hanem inkább érdek füződik hozzá, s az esemény megtörténte és igazságtartalma is megkérdőjelezhető. Álesemény lehet egy sajtótájékoztató vagy egy fizetett interjú; a PR-cikk viszont inkább a cég szolgáltatásai és termékei iránti bizalomépítő eszköz.

Egyes kutatók (például Attkisson, 2017) álhírnek tekintik a gúnyiratot, a kontextusból kiragadott információt, a ténynek beállított véleményt, az áltudományos híreket, az összeesküvés-elméleteket és az extrém elfogultságról tanúskodó bemutatást. 
Összegezve: bár az álhír újdonságnak számít, valójában csak az azt hordozó platform, az internet tekinthető újnak, hisz a propaganda már régebben is jelen volt társadalmunkban.

2018. márciusában a Michigan State University kutatói, Soroush Vosoughi, Deb Roy és Sinan Aral egy cikket publikáltak a Science magazinban, melyet az eddigi legátfogóbb és legismertebb, az álhírekről írt tanulmányként tartunk számon. A szerzők definíciója szerint az álhír igazából dezinformáció, hazugság, hamis és kitalált történet. A kutatás során egy 12 éves időszak tweetjeit vizsgálták, különbséget téve az igaz/ pontos és hazugságra épülő/hamis információ között 6 különböző, tényeket ellenőrző weboldal segítségével (factcheck.org, hoax-slayer.com, politifact.com, snopes.org, truthorfiction.com, és urbanlegends.about.com).

Vosunghi és szerzőtársai (2018) a fenti kutatás során azt találták, hogy a hamis információ jelentős mértékben messzebbre jut el, és gyorsabban, mélyebben és szélesebb körben terjed, mint az igazság, melynek hatszor annyi időbe telik a célközönség elérése. Az álhíreket tartalmazó posztokat 70\%-os valószínűséggel újból megosztják.

Goyanes és Lavin (2018) olyan demográfiai tényezőket vizsgáltak, amelyek befolyásolják a téves politikai tartalmú információk megosztásának valószínűségét. Azok, akik valószínűleg megosztják a hamis politikai híreket, elsősorban a férfiak, az idősebb emberek vagy az alacsonyabb jövedelmű egyének.

Az Európai Unió Bizottsága 2017-ben hozta létre az álhírekkel és dezinformációval foglalkozó magas szintű szakértői csoportját (High-Level Expert Group on Fake News and Disinformation), mely definiálta a dezinformációval és álhírekkel kapcsolatos jelenséget, és javaslatot is tett a probléma kezelésére.

A kutatásban részt vevők 99\%-a találkozott már álhírekkel, többnyire napi szinten a közösségi oldalakon vagy az online médiában. A legtöbb álhír a politika és a bevándorlás témájában születik. A hírek manipulálásán és hamis hírek terjesztésén túl a hamis közösségi profilok, kommentelés, twittelés is álhírnek számít. A megkérdezettek többsége ezért inkább a hagyományos médiát és a hírügynökségeket tekinti a legmegbízhatóbb hírforrásnak.

A fenti jelentés szerint a dezinformáció „olyan hamis, pontatlan vagy félrevezető információ, amelyet nyereségvágyból vagy szándékos károkozás elérése érdekében készítenek, tesznek közzé vagy terjesztenek. Ez a tevékenység fenyegetést jelenthet a demokratikus folyamatokra és értékekre, de akár a közélet egy specifikus részét is érintheti, mint például az egészségügy, tudomány, oktatás vagy gazdaság” (EU, 2018).

A dokumentum javaslatként megfogalmazza az átláthatóság ellenőrzését, a médiatudatosság fejlesztését és iskolai tárgyként történő bevezetését, oktatási programok, innovációs eszközök népszerűsítését, valamint a minőségi újságírás támogatását.

A bár egyelőre limitált számban elérhető, de dinamikusan növekvő elméleti és empirikus álhírkutatások közül Gupta és szerzőtársai (2013) az álhír terjesztésének következményeit vizsgálták, míg mások a fóbb „álhír-gyártók” motivációit (Allcott- 
Gentzkow, 2017; Subramanian, 2017; Silverman, 2016; Marwick és Lewis, 2017), valamint az olvasók értelmezéseit a valóság fogalmát illetően (Cook és szerzőtársai, 2012; Silverman, 2016).

A közösségi oldalak és a hamis hír közlésének kapcsolatáról szóló legfrissebb adatok azt mutatják, hogy az álhírt tartalmazó webhelyek forgalmának 41,8\%-a közösségi médiából származik, míg a hagyományos és a legfrissebb hírportálok csak a teljes forgalom 10\%-át teszik ki (Allcott-Gentzkow, 2017). Egyes megfigyelők a digitális dezinformáció vírusszerű terjedését a chatbotok növekedéséhez kapcsolják (Shao et al., 2017). Ferrara és szerzőtársai (2016) szerint megfigyelhető az olyan számítógépes szkriptek által ellenőrzött közösségi médiafiókok jelentős növekedése, amelyek megpróbálják magukat hitelesített emberi felhasználóként álcázni. Az ilyen hamis fiókok a Facebookon vagy az Instagramon, de különösen a Twitteren posztokat tesznek ki, kapcsolatba lépnek egymással és a többi hitelesített felhasználóval, ezáltal az embereket sebezhetőbbé teszik az online visszaélésekkel szemben (Shao et al., 2017). A Pew Kutatóközpont szerint a Twitter-felhasználók 74\%-a kap hírt ilyen forrásokból, míg a Twitter aktív fiókjainak 9-15\%-át robotok alkotják (Ferrara et al., 2017).

A hamis hírek gyorsan terjednek, mivel az információfogyasztáshoz való hozzáférés akadályai eltűntek, és a közösségi média oldalai nyílt, ingyenes és korlátlan platformokká váltak a hírek megosztására és fogyasztására (Allcott-Gentzkow, 2017). A mai médiakörnyezetben az információ szabadon áramlik az interneten. Ez a jelenség hatalmas felelősséget ró az emberekre az online információ megbízhatóságának értékelése tekintetében (McGrew et al., 2018), és a közönség számára egyre nehezebbé válik az újságírói és a nem újságírói újságtartalom megkülönböztetése, és ezáltal a hamis és a valós hír megkülönböztetése (Tandoc et al., 2017).

Azok az emberek, akik „időigényesebb” médiát használnak, nemcsak idősebbek és általában magasabb iskolai végzettséggel rendelkeznek, hanem a hírekkel kapcsolatban pontosabb elképzeléseik is vannak (Alcott-Gentzkow, 2017). Másrészt a fiatalok közösségi médiában történő hírfogyasztását „véletlenszerűként” lehet definiálni, mert számukra a hírek csupán szórakoztató információk, amelyeket az interneten találnak, miközben szörföznek a közösségi oldalakon (Gil de Zuñiga et al., 2017). Másrészt az érzelmeknek fontos szerepe van abban, hogy az emberek hogyan reagálnak a helytelen politikai feltevésekre (Weeks, 2015). Az emberek olyan információt osztanak meg, amelyek érzelmi reakciót válthatnak ki a vevőben, függetlenül attól, hogy az információ igaz-e vagy sem (Cook et al., 2012). Ennek eredményeként az újságírók tudatosan vagy tudattalanul hozzájárulhatnak az álhírek terjesztéséhez azáltal, hogy megosztják azokat a híreket, amelyek nagyobb hatással lehetnek az online társas kapcsolatukra (Barthel et al., 2016).

Az álhírekkel foglalkozó szakirodalom relevanciája ellenére ritka a demográfiai és szituatív tényezők feltárása, amelyek befolyásolhatják a hírfogyasztókat abban, hogy online politikai hamis híreket osszanak meg. A korábbi tanulmányok elsősorban 
a jelenségek prevalenciáját (Reuters Institute, 2017), az álhírek létrehozásának motivációit (Allcott-Gentzkow, 2017; Marwick-Lewis, 2017), valamint a hamis hírek terjesztésének a társadalomra, a politikai vezetőkre és az állományra gyakorolt hatását vizsgálták (Silverman, 2016; Ferrara et al., 2016; Gu et al., 2017).

Összességében véve, miért hisznek az emberek a hamis hírekben? Az egyik elmélet szerint (Allcott-Gentzkow, 2017) az ilyen információk [hamis hírek] terjesztése a közösségi hálózatokon sok hasonlóságot mutat a fertőző betegségek kialakulásával és átterjedésével. Az átviteli dinamika elemzése ezért segítséget nyújthat annak kutatásában, hogy a téves információk hogyan terjednek és versenyeznek online.

\section{Anyag és módszer}

A 21820245 sz. Social media and trust building V4-kutatásunk egy részét a fókuszcsoportos megkérdezésen alapuló kvalitatív kutatás képezte. Mind a négy részt vevő országban ugyanazon fókusz mentén zajlott a vizsgálat. Magyarországon 2019 októberében összesen 6 fókuszcsoportos vizsgálatot bonyolítottunk le. A résztvevők egyetemi hallgatók voltak, akik különböző képzési programokban tanultak. A fókuszcsoportok 8-12 résztvevőből álltak, és általában 60-90 percig tartottak.

A társadalomtudományi kutatásban hagyományosan alkalmazott módszer (Merriam, 2009), de az elmúlt években A fókuszcsoportokat már régóta használják a marketingben és a társadalomtudományokban (Casey és Krueger, 2000).

A fókuszcsoportos vizsgálat készítésének metódusát először Bogardus (1926) jegyezte le. A fókuszcsoport tehát egy „olyan kutatási módszert jelent, melynek során az adatok úgy keletkeznek, hogy a kutatás alanyai csoportosan kommunikálnak egy adott témáról" (Vicsek, 2006: 17). A fókuszcsoportos interjúk olyan interjúk, amelyeket a résztvevők egy csoportjával folytatunk információgyűjtés céljából. A fókuszcsoportos beszélgetéseket akkor érdemes használni, amikor mélyebben szeretnénk egy kérdést megérteni, mint amennyit egy felméréssel kaphatnánk. Fontos jellemzője a módszernek, hogy információt szerzünk a résztvevők nézeteiről, nem pedig tanítjuk és informáljuk őket (Vicsek, 200: 18). A fókuszcsoport alkalmas eszköz, ha a vizsgált jelenség egyes dimenzióinak a megismerése a cél, amiről mg nincs sok információnk (Babbie, 2003).

Általában feltáró jellegü kutatási kérdések vizsgálatára alkalmas. Jelen tanulmányban a következő kutatási kérdésekre adunk választ:

- Ismerős Önöknek az “álhír” elnevezés?

- Hol találkozunk e jelenséggel?

- Mennyire ismeri és tudja megkülönböztetni a valós híreket az álhírektől? 
- Hogyan teszi ezt? Kérem, illusztrálja egy pár példával.

- Milyen specifikus hírforrásokra keres rá általában?

- Hol tanulja ezt a technikát?

- Mennyit hallott erről az iskolában? Kérem, említsen meg egy pár konkrét esetet.

Casey és Krueger (2000: 11) szerint a fókuszcsoport „természetesebb környezetet biztosít, mint az egyéni interjú, mivel a résztvevők másokat is befolyásolnak és fordítva, akárcsak a valós életben".

A fókuszcsoportos interjút megfelelő módszernek tekintettük, hisz célunk az volt, hogy egy jól körülhatárolható kérdést, problémát vizsgáljunk, azaz jól megragadható fókusza volt kutatásunknak. Liamputtong (2011) ajánlásának megfelelően a moderátor mellett feljegyzéskészítő is dolgozott, aki lényegében létrehozza a tanulmányban szereplő adatok első értelmezési tervezetét.

\section{Eredmények}

Fontos, hogy nem egy-egy ember, hanem egy csoport véleményének megismerése volt a célunk, akiket az általunk fókuszba helyezett probléma érint. A megkérdezettek problémafelfogása és megoldási javaslatai állnak a kutatásunk középpontjában. Első, bemelegítő jellegű kérdésünk arra vonatkozott, hogy a megkérdezett - fóként „Z” generációba tartozó - fiatalok egyáltalán ismerősnek vélik-e az álhír elnevezést, hallottak-e már róla. Nem meglepő módon egyöntetűen igennel feleltek, nem volt olyan egyik fókuszcsoportban sem, hogy valaki ne hallott volna erről. Mindenki tudta, mit jelent, és mindenki azt állította, hogy személyesen is találkozott már álhírekkel, saját bevallása szerint nem is egyszer.

Számunkra érdekesebb volt a kutatás szempontjából, hogy amikor arról érdeklődtünk, hogy hol találkozunk a jelenséggel, gyakorlatilag egységesen érkezett a válasz, hogy „mindenhol”. Az általunk megkérdezettek úgy érzékelik, hogy életük minden területén találkoznak álhírekkel, melyek miatt minden hírrel szemben óvatosak, nagyon megnézik, hogy hol, mit, hogyan hallanak/olvasnak. Azt mondják, hogy nemcsak az online világ sajátja az álhír, hanem a nyomtatott sajtó és a televízió is tele van vele, sőt meglátásuk szerint még az egyetemeken is találkoznak vele, amikor minden felsőoktatási intézmény a sajátját állítja legjobbnak, és azt hangoztatja. Azonban érdekes módon azt kiemelték, hogy a televízióban elhangzottakat mégis hitelesnek tekintik - annak ellenére, hogy korábban úgy nyilatkoztak, hogy tudják, hogy ott is sok az álhír - mivel úgy gondolják, azt azért biztosan „sok ember jóváhagyta”. Ebből arra is következtethetünk, hogy van egy bizonyos kvantitatív szempontrendszerük is a hír valóságtartalmának megítélésekor. 
Úgy vélik, hogy egyszerre nagyon egyszerü és mégis nehéz felismerni, megkülönböztetni az álhírt a valós hírtől. Többnyire a józan eszükre és a meglévő háttértudásukra hagyatkoznak ebben a kérdésben. Arra a kérdésre, hogy hogyan tudják eldönteni, hogy valós vagy álhírrel találkoznak, számos választ adtak. Többnyire leellenőrzik a szerző Facebook-profilját, fényképét és a felhasznált forrásokat, továbbá elolvassák a poszt alatti kommenteket, valamint megnézik a kedvelőket is. Amennyiben sok ismerősük kedvelte, nagyobb eséllyel tartják valósnak. Úgy tapasztalják, hogy az Instagramon való ellenőrzés megbízható, mert ott a felhasználókat ellenőrzik és „hitelesítik”. Gyanúra ad okod számukra, ha kevés like van a poszt alatt, vagy a cím nagyon „szenzáció-hajhász”, illetve a cím és a tartalom nem fedik egymást, és a cím csupa nagybetűvel vagy vegyesen kis- és nagybetűkkel van írva. Még inkább gyanús, ha helyesírási, központozási hibák sokasága van a cikkben, illetve ha a Google segítségével nem tudják visszakeresni más forrásból a tartalmat. Megbízhatónak tartják a hírt, amennyiben ellenőrzött, lektorált, a szerző ismert, és még forrásmegjelölés is van benne. Kiemelték a képek és videók szerepeltetését is, melyek alkalmazása hitelesebbé teszi számukra a tartalmat. A hatóságok, hivatalos szervek által kiadott hírek, viedók általában valósnak tekinthetőek megítélésük alapján, azokban általában megbíznak.

Kutatói szemmel roppant izgalmasnak tartjuk, hogy mikor megkérdeztük, hogy hol tanulták ezeket a technikákat, amikkel megkülönböztetik az álhíreket a valós hírektől, azt a választ kaptuk, hogy „sehol, mindenki a saját bőrén tanulja meg”. Sokan úgy vélik, hogy ez egy készség, amit nem is igazán lehet tanítani. Mások azért örülnének, hogy lenne ilyesmivel foglalkozó kurzus az iskolában, illetve preferálják a szülőkkel való kommunikálást erről. Úgy érzik, hogy ez szülői feladat is, hogy felkészítsék gyermekeiket az álhírek felismerésére, védekezésre ezekkel szemben.

Megkérdezettjeink között akadtak néhányan, akik arról számoltak be, hogy az egyetemen bizonyos kurzusok (például desztinációmenedzsment a turizmusórán) keretein belül beszéltek a közösségi médiáról, az okoseszközökről, a Facebook-statisztikákról. Mások azt nyilatkozták, hogy még a középiskolában voltak olyan órái, melyeken feladat volt, hogy tartsanak előadást az e-mail és a közösségi média használatáról, a felhasználói biztonságról, de a többség az iskolában nem hallott sem a közösségi média biztonságos használatáról, sem az álhírek elleni védekezésről. A tanáraik maximum arra hívták fel a figyelmüket, hogy késő éjszaka ne Facebook-ozzanak, vagy ne álljanak ott szóba idegenekkel - melyek hasznos tanácsok, csak nem elegendőek. Fontosnak tartották még megemlíteni, hogy azt jó dologként élik meg, hogy az emberek figyelmeztetik egymást többnyire posztokban, ha átverésről van szó. 


\section{Következtetések, javaslatok}

Összességében elmondhatjuk, hogy a fókuszcsoportos vizsgálatban részt vevő egyetemista fiatalok teljes mértékben tisztában vannak az álhír fogalmával, mindannyian tudják, mit jelent, és van empirikus tapasztalatuk is ezzel kapcsolatosan. Az eredmény abból a szempontból nem tekinthető különösebben meglepőnek, hogy a megkérdezettek a „Z” generáció, vagyis az első multitasking generáció tagjai, akik gyakorlatilag már a közösségi média használatába nőttek bele, s szocializációjukban jelentős szerepet játszott már a virtuális közösségi tér. Meglepő azonban, hogy kezelni mégsem tudják teljes magabiztossággal az ott szereplő információkat. Ez természetesen részben magyarázható a hatalmas mennyiség problematikájával is, de meglátásunk szerint egyéb faktorok - például az oktatás - is szerepet játszhatnak.

Mindazonáltal az is világosan kirajzolódott, hogy nincs egységes módszertan a valós és álhírek megkülönböztetésére, valamint, hogy az oktatás/felsőoktatás jelenleg nem nyújt ebben hathatós segítséget a felnövekvő értelmiségnek. Alkalmazkodva a gyorsan változó és informatikai szempontból exponenciális növekedést mutató környezethez, érdemes lehet elgondolkodni egy olyan megoldáskészlet kidolgozásán, mely hathatós segítséget nyújthatna a fiataloknak a közösségi médiában való biztonságosabb, egyértelműbb eligazodáshoz. A szülők felelőssége természetesen továbbra is megvan, ám javaslatként megfogalmazható lenne egy olyan kurzus indítása, mely a közösségi média biztonságos használatára tanítaná a hallgatókat, és melyben időt szentelnének az álhír kontra valós hír témakörnek is.

\section{Hivatkozott források}

[1.] Ahlers, D. (2006): News consumption and the new electronic media. Harvard International Journal of Press/Politics 11(1): 29-52.

[2.] Allcott, H. and Gentzkow, M. (2017): Social media and fake news in the 2016 election. Journal of Economic Perspectives 31(2): 211-36.

[3.] Allcott, H. and Gentzkow, M. (2017): Social media and fake news in the 2016 election. Journal of Economic Perspectives 31(2): 211-36.

[4.] Attkisson, Sharyl (2017): The Smear. How Shady Political Operatives and Fake News Control What You See, What You Think, and How You Vote. New York: HarperCollins.

[5.] Babbie, E. (2003): A társadalomtudományi kutatás gyakorlata. Budapest: Balassi Kiadó. 
[6.] Barthel M., Mitchell, A. and Holcomb, J. (2016): Many Americans believe fake news is sowing confusion. Pew Research Center. http://www.lse.ac.uk/ media-andcommunications/assets/documents/research/working-paperseries/WP52.pdf [Letöltés ideje: 2019. október 24].

[7.] Baum, M., Mele, N., Lazer, D., Grinberg, N., Joseph, K., Hobbs, W., Friedland, L., and Mattsson, C. (2017): Combating Fake News: An Agenda for Research and Action. https://shorensteincenter.org/combatingfake-newsagenda-for-research/ [Letöltés ideje: 2019. augusztus 23].

[8.] Casey, M. A. \& Kueger, R.A. (2000): Focus groups: A practical guide for applied research. (3rd ed.). Thousand Oaks, CA: Sage.

[9.] Cook, J., Ecker, U., Lewandowsky, S. and Schwarz, N. (2012):Misinformation and its correction continued influence and successful debiasing. Psychological Science in the Public Interest 13: 106-31.

[10.] European Commission (2018): Final report of the High Level Expert Group on Fake News and Online Disinformation. https:/ec.europa.eu/digital-singlemarket/en/news/final-report-high-level-expert-group-fake-news-and-onlinedisinformation [Letöltés ideje: 2019. október 24].

[11.] Ferrara, E., Varol, O., Davis, C., Menczer, F. and Flammini, A. (2016): The rise of social bots. Communications of the ACM 59(7): 96-104.

[12.] Gil de Zúñiga, H., Weeks, B., and Ardèvol-Abreu, A. (2017): Effects of the news-finds-me perception in communication: social media use implications for news seeking and learning about politics. Journal of Computer-Mediated Communication 22(3): 105-23.

[13.] Goyanes, M. (2014): An empirical study of factors that influence the willingness to pay for online news. Journalism Practice 8(6): 742-57.

[14.] Goyanes, M. Lavin, A. (2018): The sociology of fake news. LSE Media and Communications. http://www.lse.ac.uk/media-and-communications/asset s/documents/research/working-paper-series/WP55.pdf [Letöltés ideje: 2019. október 24].

[15.] Gu, L., Kropotov, V., and Yarochkin, F. (2017): The fake news machine, how propagandists abuse the internet and manipulate the public. http:// documents.trendmicro.com/assets/white_papers/wp-fakenews-machine-howpropagandists-abuse-the-internet.pdf [Letöltés ideje: 2019. augusztus 23]. 
[16.] Gupta, A., Lamba, H., Kumaraguru, P., and Joshi, A. (2013): Faking Sandy: characterizing and identifying fake images on Twitter during Hurricane Sandy. Proceedings of the 22nd International Conference on World Wide Web: 729-36.

[17.] Lakoff, G. (2002): Moral Politics. How Liberals and Conservatives Think. Chicago: University of Chicago Press.

[18.] Liamputtong, P. (2011): Focus Group Methodology Principle and Practice. Sage Publications.

[19.] Marwick, A. and Lewis, R. (2017): Media manipulation and disinformation online. https://datasociety.net/pubs/oh/DataAndSociety_ MediaManipulationAndDisinformationOnline.pdf [Letöltés ideje: 2019. augusztus 23].

[20.] McGrew, S., Breakstone, J., Ortega, T., Smith, M. and Wineburg, S. (2018): Can students evaluate online sources? Learning from assessments of civic online reasoning. Theory \& Research in Social Education: Online First. Meyer.

[21.] Merriam, S. B. (2009): Qualitative Research: A guide to design and implementation. San Francisco, CA: Jossey-Bass.

[22.] Meyer, P. (2004): Saving journalism: How to nurse the good stuff until it pays. Columbia Journalism Review 43(4): 55-8.

[23.] Reuters Institute Digital News Report (2017): https://papers.ssrn.com/sol3/ papers.cfm?abstract_id=3026082 [Letöltés ideje: 2019. augusztus 23].

[24.] Shao, C., Ciampaglia, G., Varol, O. Flammini, A. and Menczer, F. (2017): The spread of misinformation by social bots. https://arxiv.org/pdf/1707.07592. pdf [Letöltés ideje: 2019. október 24].

[25.] Shu, K., Sliva, A., Wang, S., Tang, J. and Liu, H. (2017): Fake News Detection on Social Media: A Data Mining Perspective. ACM SIGKDD Explorations Newsletter 19(1): 22-36.

[26.] Silverman, C. (2016): This analysis shows how viral fake election news stories outperformed real news on Facebook. Buzzfeed. https://www.buzzfeed. $\mathrm{com} /$ craigsilverman/viral-fake-election-news-outperformedreal-newson-facebook?utm_term=.qr5jwepJ9\#.mtWol8APj [Letöltés ideje: 2019. október 24].

[27.] Subramanian, S. (2017): Inside the Macedonian fake-news complex. Wired magazine. https://www.wired.com/2017/02/veles-macedonia-fake-news/ [Letöltés ideje: 2019. augusztus 23]. 
[28.] Tandoc, E., Ling, R., Westlund, O., Duffy, A., Goh, D. and Wei, L. (2017): Audiences' acts of authentication in the age of fake news: a conceptual framework. New Media and Society: Online First.

[29.] Váradi M. M. (2008): Fókuszcsoportos interjú. In Kovács Éva: Közösségtanulmány. PTE-BTK Kommunikáció és Médiatudományi Tanszék.

[30.] Vicsek L. (2006): Fókuszcsoport. Osiris: Budapest.

[31.] Vosoughi, S. Roy D. and Ara, S. (2018): The spread of true and false news online. Science 359, Issue 6380, pp. 1146-51.

[32.] Weeks, B. (2015): Emotions, Partisanship, and Misperceptions: How Anger and Anxiety Moderate the Effect of Partisan Bias on Susceptibility to Political Misinformation. Journal of Communication 65(4): 699-719. 


\section{Szerzők:}

\section{Dr. Czeglédi Csilla \\ $\mathrm{PhD}$}

egyetemi docens

Eötvös Loránd Tudományegyetem

Pedagógiai és Pszichológiai Kar

Felnőttképzés-kutatási és Tudásmenedzsment Intézet

czegledi.csilla@ppk.elte.hu

\section{Dr. Veresné dr. Valentinyi Klára}

$\mathrm{PhD}$

egyetemi docens

Szent István Egyetem

Gazdaság- és Társadalomtudományi Kar veresne.valentinyi.klara@gtk.szie.hu

\section{Borsos Eszter}

egyetemi tanársegéd

Szent István Egyetem

Gazdaság- és Társadalomtudományi Kar

Dékáni Titkárság

borsos.eszter@gtk.szie.hu

\section{Dr. Szira Zoltán}

$\mathrm{PhD}$

egyetemi docens

Szent István Egyetem

Gazdaság- és Társadalomtudományi Kar szira.zoltan@gtk.szie.hu

\section{Dr. Varga Erika}

$\mathrm{PhD}$

egyetemi docens

Szent István Egyetem

Gazdaság- és Társadalomtudományi Kar varga.erika@gtk.szie.hu 